make mankind become continually nobler, happier, and healthier; whilst those who imagine that our sole aim is to make man a stronger animal or a better beast of burden are utterly ignorant of the meaning of the eugenic ideal. But science, whilst giving us good grounds for hope, also issues a grave warning concerning the danger of national deterioration resulting from the unchecked multiplication of inferior types. In the past many nations of the first rank, when apparently advancing without check on the path of prosperity, have begun to decay from unseen causes, and have in time so fallen from their high estate as to cease to count as factors making for progress. A determination that such a downfall shall not be the fate of his nation is a sentiment felt by every man who is animated by the eugenic ideal, an ideal to be followed like a flag in battle without thought of personal gain.

Leonard Darwin

\section{FREDERICK MORTON CHAMBERLAIN}

Frederiok Morton Chamberlain died on August 17, 1921, in a hospital in Oakland, California, after a long and sometimes hopeful fight against tuberculosis. He became seriously ill in July, 1913, while on the Pribilof Islands, and although he partially regained his health for short periods, he was at no time thereafter able to resume his usual activity. The U. S. Bureau of Fisheries has thus lost one of its most faithful employees, one whose clear, keen mind and charming personality will long be mourned by his associates.

Mr. Chamberlain was born in Indiana, June 29, 1867. He graduated at the State Normal School at Terre Haute in 1894, the State University at Bloomington in 1896 and the George Washington School of Law in Washington, D. C., in 1913. A close friendship began at the Indiana colleges with (then) Professor Barton Warren Evermann with whom later he was associated in many scientific investigations.

In the fall of 1896 he followed Dr. Evermann to the U. S. Bureau of Fisheries (then the United States Fish Commission) with which he was connected throughout the re- mainder of his active career. In 1897 he and Dr. Evermann carried on fishery investigations in some of the southern states. Later in the same year he joined the Fisheries Steamer Albatross and accompanied her to Alaskan waters for a season of work in the fisheries. The two following years the investigation of salmon in the streams of California occupied his attention. In this he was associated with Cloudsley Rutter. In 1900 and 1901 he was back on the Albatross engaged on Alaska fishery problems, and in 1902 he worked in Hawaii.

During the summers of 1903, 1904 and 1905, a work on the life history and young stages of Alaskan salmon was completed. The report which was published in the Report of the Commissioner of Fisheries for 1906, marks the beginning of an epoch in the study of these important food fishes, and its importance has only lately come to be realized in fish-culture. The clear, concise language shows the hand of the master workman, and the thoroughness with which each problem was attacked is the chief mark of the true scientist. His health failed in 1905, while he was in the field on these investigations, but apparent full recovery was made after a short stay in Arizona:

The Albatross sailed on a winter cruise to the south Pacific for Alexander Agassiz during the winter of 1904 and 1905 and Mr. Chamberlain accompanied the vessel as naturalist. The summer of 1906 was spent with the ship in north Pacific and Japanese waters, while from 1907 to 1910 he was in the Philippines. The last cruise closed his connection with this famous vessel. During her most active period Mr. Chamberlain was aboard and attended to the preparation of a great many thousand specimens of marine animals for later examination of specialists. The impersonal manner in which the records of the Albatross must necessarily be kept is regrettable. Thus some pieces of iron, fastened together in the form of a ship and named after a bird will live for centuries in the annals of science but the guiding hand which caused the machinery to produce the treasures of the deep, passes to oblivion, unmourned except by his 
circle of personal friends. Mr. Chamberlain was instrumental in the bringing to the surface many hundreds of strange new mollusks, crustaceans and echinoderms, yet apparently his name has not been bestowed upon a single one. Two fishes and an Alaskan bird, however, have been named for him.

During the seasons of 1911 and 1912, Mr. Chamberlain filled the position of Alaska salmon agent and worked in the northern territory. In 1913 he was appointed naturalist of the Fur-seal Service and reached the Pribilof Islands just three days before the severe attack from which he never fully recovered. He was conveyed to the states, desperately ill, and the climate of Arizona again helped to only a partial recovery.

\section{G. Dallas Hanna}

\section{MUSEUM,}

CALIFornia ACADEMY of ScIENCES

\section{SCIENTIFIC EVENTS}

MOVEMENT OF THE POPULATION IN THE

DURING 1919 and 1920, according to data recently published by the government statistical bureau and quoted in the Journal of the American Medical Association, the number of marriages in the German empire exceeded, by a considerable margin, the figures for the prewar period. In the five years from 1914 to 1918, inclusive, almost half a million marriages less were contracted than would normally have been the case. However, this notable falling off in marriages during the years of the war was compensated for, in the main, during 1919 and 1920; for in these two years the number of marriages reached the high figures of 842,787 and 851,508, respectively. Whereas in 1913 there were only 7.7 marriages to 1,000 inhabitants, in 1920 there were 14.8. Normally, forty marriages to 1,000 inhabitants could have been expected during the five years of the war, but, instead, only 25.1 marriages were entered upon. Eighty-two per cent. of the decrease has been made up during the last two years.

In 1914, the number of children born was 1,830,892. In 1915 it had fallen to $1,040,209$ and in 1917 to 939,938 . In 1918 the number had risen again to 956,251 . In place of the normal 8,950,000 births in the period from 1914 to 1918 , we find only $4,550,000$ recorded, which signifies a loss of $4,400,000$ due to the war. In 1919 the total number of children born was still about 400,000 below normal. Not until 1920 was the number of births again about normal, the records showing 1,512,162 births, or 27.1 to every 1,000 inhabitants, as compared with $1,707,834$ births, or 28.5 per thousand inhabitants in 1913. The number of deaths in 1920 was $888,795,16.3$ deaths to every 1,000 inhabitants, the mortality for 1919 having been 16.1 per thousand. The last year before the war (1913) showed a mortality of 924,919 , or 15.8 per thousand inhabitants. Especially during the first three months of 1920 the mortality rate was very high. More particularly, diseases of the respiratory organs and influenza exacted many victims during this period. In Berlin, more than a third of all deaths, namely, 37.7 per cent., were due to diseases of the respiratory organs, whereas during the first quarter of 1913 only one seventh of all deaths in Berlin were ascribable to such causes. During the last three quarters of 1920 , the mortality rate fell considerably, having been $14.9,14.5$ and 15.4 per thousand inhabitants, as against mortality rates of 19.9, 22.0, 19.7, 20.8 and 25.1 for the five-year period from 1914 to 1918, inclusive. The year 1919 showed a slight excess of births over deaths and the year 1920 a still greater excess.

\section{ACCIDENTS DUE TO EYE DEFECTS}

The Committee on Elimination of Waste in Industry of the American Engineering Council has made public a report on accidents due to eye defects. The total number of industrial blind in the United States is given as 15,000 or 13.5 per cent. of the total blind population, this type of injury being the leading causative factor of blindness, according to the report, which was prepared by Earle B. Fowler. The eye is involved in 10.6 per cent. of all permanently disabling accidents. 